\title{
Hormonal regulation of mRNA stability and RNA-protein interactions in the pituitary
}

\section{J M Staton, A $\mathbf{M}$ Thomson and $\mathbf{P}$ J Leedman}

\author{
Laboratory for Cancer Medicine and University Department of Medicine, Royal Perth Hospital and \\ University of Western Australia, Western Australian Institute for Medical Research, Perth WA 6000, \\ Australia \\ (Requests for offprints should be addressed to P J Leedman, University Department of Medicine, \\ Royal Perth Hospital, Box X2213 GPO, Perth, WA 6001, Australia; Email: peterl@cyllene.uwa.edu.au)
}

\begin{abstract}
Regulating gene expression from DNA to protein is a complex multistage process with multiple control mechanisms. Transcriptional regulation has been considered the major control point of protein production in eukaryotic cells; however, there is growing evidence of pivotal posttranscriptional regulation for many genes. This has prompted extensive investigations to elucidate the mechanisms controlling RNA processing, mRNA nuclear export and localization, mRNA stability and turnover, in addition to translational rates and posttranslational events. The regulation of mRNA stability has emerged as a critical control step in determining the cellular mRNA level, with individual mRNAs displaying a wide range of stability that has been
\end{abstract}

linked to discrete sequence elements and specific RNA-protein interactions. This review will focus on current knowledge of the determinants of mRNA stability and RNA-protein interactions in the pituitary. This field is rapidly expanding with the identification of regulated cis-acting stabilitymodifying elements within many mRNAs, and the cloning and characterization of trans-acting proteins that specifically bind to their cognate cis elements. We will present evidence for regulation of multiple pituitary genes at the level of mRNA stability and some examples of the emerging data characterizing RNA-protein interactions.

Fournal of Molecular Endocrinology (2000) 25, 17-34

\section{INTRODUCTION}

Though small, the pituitary, which is situated centrally in the sella turcica, is a major gland that synthesizes and secretes at least six hormones essential for maintaining body metabolism and homeostasis, in addition to mental function. These hormones regulate such diverse functions as growth (growth hormone, GH) and development and function of the thyroid gland (thyroid stimulating hormone, TSH), adrenal cortex (corticotropin, $\mathrm{ACTH}$ ), male and female gonads (follicle stimulating hormone, FSH; leuteinising hormone, $\mathrm{LH}$ ) and breasts (prolactin, PRL). The posterior pituitary contains the termini of neurons originating from the hypothalamic nuclei responsible for synthesis of oxytocin and arginine vasopressin (AVP), hormones involved in suckling and body water homeostasis, respectively. Lesions in the pituitary often produce tumors and symptoms referable to under- or overexpression of these hormones.

There has been great interest in understanding the regulation of expression of each of the pituitary hormones ever since 1886, when Pierre Marie described the association of pituitary enlargement and acromegaly. How these hormones regulate the expression of other genes is also of great interest. Each pituitary hormone has been purified, characterized, cloned and its functional roles clearly delineated. Complex feedback loops have been described for many of the hormones; however, we are only just beginning to understand the complexity of the regulation of expression of the genes coding for each of these hormones. This is also true 


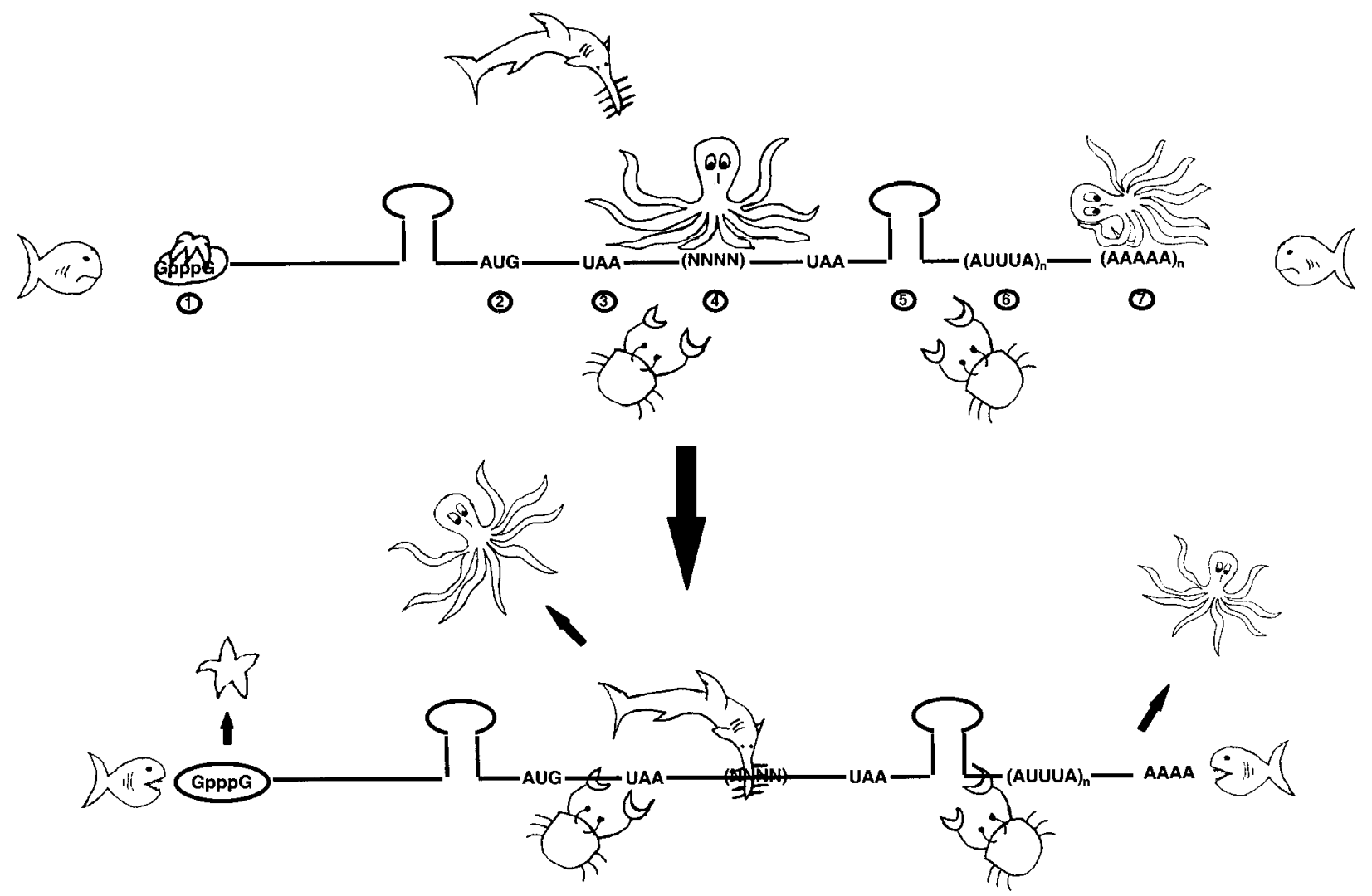

FIGURE 1. Factors affecting mRNA stability: locations of mRNA sequence elements involved in regulating mRNA decay. (1) Cap structure, (2) 5'UTR sequences, (3) premature termination codons, (4) open reading frame sequences, (5) 3'UTR sequences including stem-loops and (6) AU-rich elements, and (7) the poly(A) tail. The mRNA may be protected from degradation by the binding of RNA-binding proteins (octopuses) and cap-binding protein (starfish), which protect it from exonucleases (fish), or non-specific endonucleases (crab). Specific sites may be targeted by a specific endonuclease (e.g., swordfish). Adapted from Laird-Offringa (1991).

in the study of regulation of their cognate receptors and other target genes.

Regulation of gene expression occurs at multiple levels, including transcription, RNA processing, mRNA nuclear export and localization, mRNA decay, translation and posttranslational events. However, the focus of this review will be on the current knowledge of posttranscriptional regulatory mechanisms at the level of mRNA stability. A large number of hormones have been shown to influence the mRNA stability of both nonpituitary and pituitary genes. There will be a noticeable bias towards the anterior pituitary, as this reflects the current research status, though a few examples do exist for posttranscriptional gene regulation in the posterior pituitary. Before embarking on a detailed discussion of the pituitary, in the following sections we provide an overview of the mechanisms involved in the regulation of mRNA stability.

\section{MRNA STRUCTURE AND FUNCTION AND RNA-PROTEIN INTERACTIONS}

After transcription, pre-mRNAs undergo major processing in the nucleus, whereby introns are removed and exons ligated (mRNA) within a RNA-protein complex known as the spliceosome. The coding sequence of eukaryotic mRNAs is flanked by their $5^{\prime}$ and $3^{\prime}$ untranslated regions (UTRs) (Fig. 1). The 5' and 3' UTRs of mRNAs may contain cis-acting elements that control the translation, degradation and localization of transcripts (Wilson \& Brewer 1999). In addition, the 5' and $3^{\prime}$ terminal nuclear modifications of eukaryotic mRNAs, the cap ( $\left.{ }^{7} \mathrm{mGpppN}\right)$ and poly(A) tail respectively, play critical roles in mRNA translation and stability (Wickens \& Stephenson 1984, Strickland et al. 1988, Gallie 1991, Keller \& Minvielle-Sebastia 1997, Wickens et al. 1997, Deo et al. 1999) (Fig. 1). RNA transport from the 
nucleus takes place via localizing cis elements and nuclear transport trans-acting proteins (for further details see Izzauralde \& Mattaj 1995, Izzauralde et al. 1995, Michael \& Dreyfuss 1995, Meyer et al. 1996, Visa et al. 1996).

After mRNAs have been released from the nuclear export machinery, they are bound by a cytoplasmic cap-binding complex, eIF4F, that is composed of three sub-units: eIF4E (which directly contacts the ${ }^{7} \mathrm{mG}$ cap), the RNA helicase, eIF4A, and eIF4 G (Dreyfuss et al. 1996, Sonenberg 1996, Waskiewicz et al. 1999, Pyronnet et al. 1999) which are bound in the polyribosome complex (Mangus \& Jacobson 1999). eIF4E is believed to represent a rate-limiting factor in translation, and it is therefore a potential target for translational control (Marcotrigiano et al. 1999). Work from many laboratories has shown recently that the binding of the heterotrimeric complex, eIF4F, to the cap structure is required to initiate the assembly of a translation-competent ribosome on the capproximal region of most cellular mRNAs (Sachs et al. 1997, Waskiewicz et al. 1999, Pyronnet et al. 1999). Other proteins that bind with high affinity to this cap-proximal region block the entry of the small ribosomal subunit and repress translation (e.g., iron-responsive elements (IREs) and ironregulatory proteins (IRPs); Muckenthaler et al. 1998, see below).

The role of the cap in mRNA stabilization has been demonstrated clearly in Saccharomyces cerevisiae, in which decapping of the $5^{\prime}$-terminus represents part of a common degradation pathway for stable and unstable mRNAs (Caponigro \& Parker 1995, Tuite 1996, Deo et al. 1999, see below). Decapping is preceded by deadenylation (removal of the poly(A) tail at the $3^{\prime}$-terminus), which reflects the role of the poly(A) tail in translation regulation and mRNA turnover and indicates an important communication between the two termini (Strickland et al. 1988, Jacobson \& Peltz 1996, Tanguay \& Gallie 1996, Deo et al. 1999).

Inherently unstable mRNAs can approach a new steady-state level more rapidly than stable mRNAs after changes in transcriptional activity (Hargrove \& Schmidt 1989, Beelman \& Parker 1995, Wilson \& Brewer 1999). This property of unstable mRNAs allows their cytoplasmic concentrations, and hence their potential for translation, to be altered quickly in response to a change in the transcription rate. A number of mRNAs display altered stability in response to hormonal, developmental and environmental factors (Wilson \& Brewer 1999, Williams et al. 1993). These inducible effects on mRNA stability have the potential to change cytoplasmic
mRNA concentrations rapidly without alteration in transcriptional activity, or to augment the magnitude of mRNA induction by coordinating changes in transcription and mRNA stability.

In summary, specific fundamental RNA-protein interactions occur within both the nucleus (mRNA processing and localization) and the cytoplasm (localization, translation, mRNA stability) of eukaryotic cells, and it is these interactions that govern the subsequent rate of decay of a particular mRNA. This review will focus predominantly on cytoplasmic mRNA decay in the pituitary.

\section{CYTOPLASMIC mRNA DECAY: SEQUENCE DETERMINANTS}

mRNA decay is not a random, indiscriminate nuclease degradation process, but a precise process dependent on a variety of specific cis-acting stability-modifying mRNA sequences and transacting protein factors (Figs 1, 2). Nucleases, mRNA sequence elements and regulated RNA-binding proteins required for the promotion or inhibition of mRNA decay have been identified, and the molecular mechanisms involved are being elucidated. Generically, mRNA decay is triggered by at least three types of initiating event: poly(A) tail shortening, arrest of translation at a premature nonsense codon, and endonucleolytic cleavage (Figs 1,2) (Stevens 1993). Steps subsequent to poly(A) tail shortening or premature translational termination converge in a pathway that progresses from removal of the $5^{\prime}$ cap to exonucleolytic digestion of the body of the mRNA (Jacobson \& Peltz 1996, Wilson \& Brewer 1999). Fragments generated by endonucleolytic cleavage are most probably removed by exonucleolytic decay also (Fig. 2). Recent studies have indicated that decay of mRNA commences while the mRNA is still being translated and is still attached to the polyribosomal complex (Mangus \& Jacobson 1999). However, translation initiation is required to induce mRNA decay (Posch et al. 1999). The role of different mRNA sequences and structures (cis elements) and RNA-binding proteins (trans elements) in the determination of mRNA decay will be discussed below.

\section{Exonuclease mRNA decay: poly(A) tail-dependent degradation}

Role of $5^{\prime}$ cap and poly $(A)$ tail

The mRNA $5^{\prime}$ cap structure generally remains unchanged after mRNA export into the cytoplasm. The $5^{\prime}-5^{\prime}$ phosphodiester bond of the cap makes it inherently resistant to general ribonucleases 


\section{DEADENYLATION-DEPENDENT DECAY}

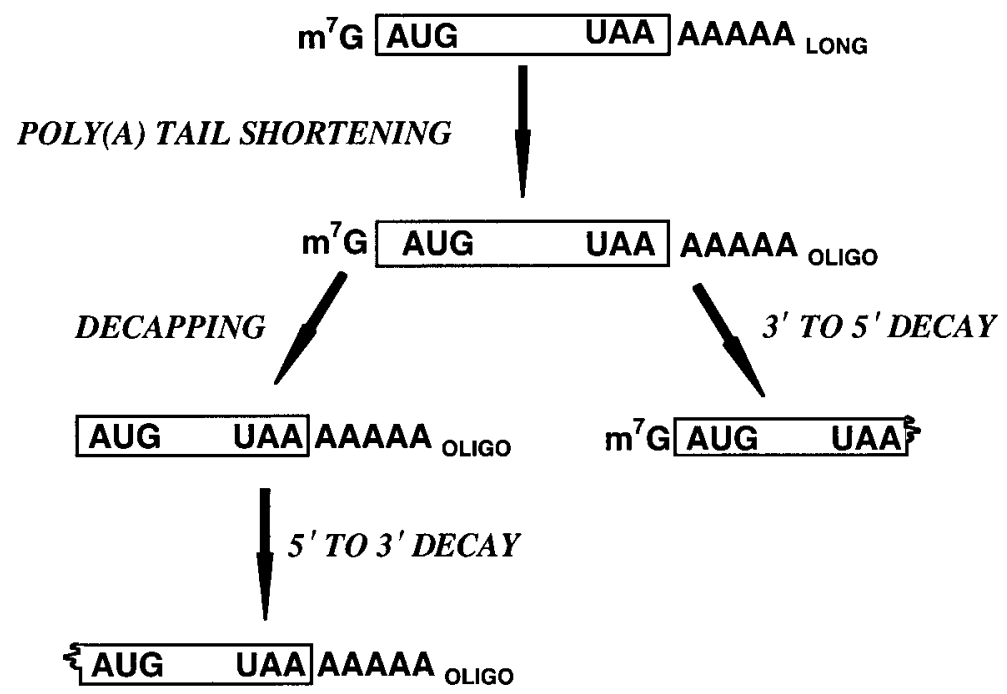

DEADENYLATION-INDEPENDENT DECAY
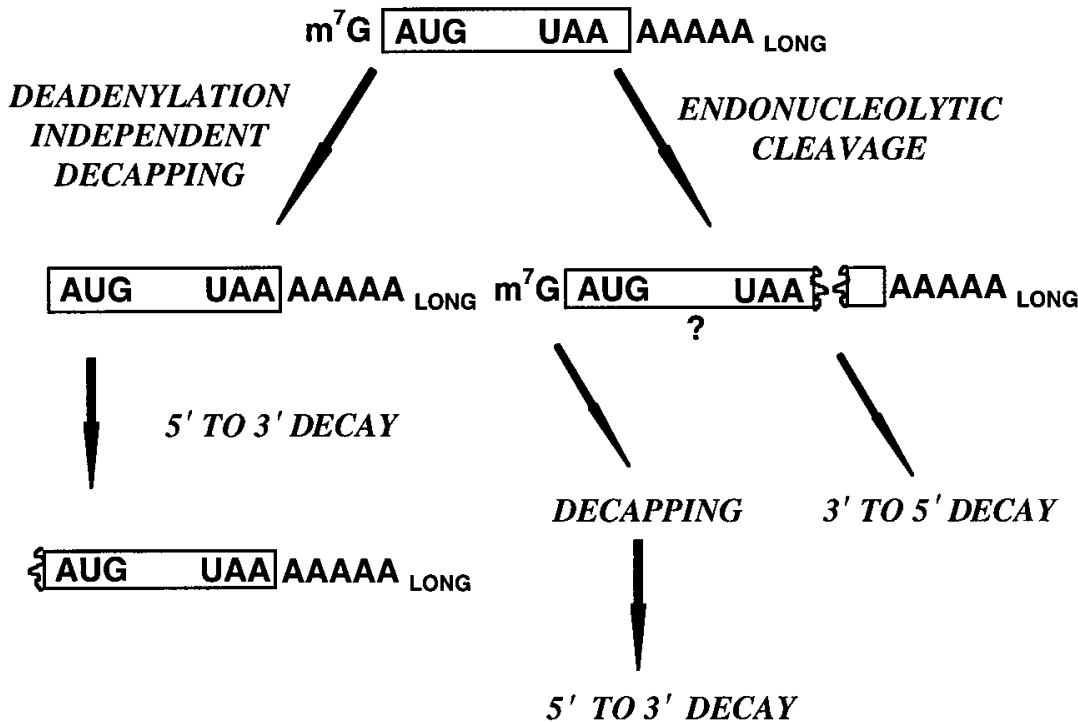

FIGURE 2. mRNA decay pathways in eukaryotes. The top pathway depicts deadenylation-dependent decay, followed by decapping and 5 '-3' decay, or $3^{\prime}-5^{\prime}$ decay by exonucleases and/or endonucleases. The vast majority of eukaryotic mRNAs may undergo decay in this way unless they are specifically targeted for rapid deadenylation-independent decapping (bottom) by a nonsense codon, or for endonucleolytic cleavage, by the presence of a cleavage site. After deadenylation-independent decapping (bottom pathway), mRNA is degraded in a $5^{\prime}-3^{\prime}$ manner. Endonucleolytic cleavage of mRNA may serve as a one-step deadenylation that leads to decapping and 5-3' decay. Adapted from Beelman \& Parker (1995) with permission. 
(Furuichi et al. 1977, Shimotohno et al. 1977), though binding of the eIF4 G complex may also be responsible for protecting this region from nuclease attack (Stevens 1993, Dreyfuss et al. 1996).

Most eukaryotic mRNAs have a $3^{\prime}$ poly(A) tract; though contentious, this is not regarded as a determinant of mRNA stability, even though it does influence mRNA decay (Strickland et al. 1988). Poly(A) tracts are gradually shortened in the cytoplasm in an mRNA- and organism-specific manner, and may be completely removed in some cases (Wilson \& Brewer 1999, Imataka et al. 1998, Jacobson \& Peltz 1996). In some instances, shortening of the tail to an oligo(A) form is the rate-determining event that triggers turnover of the body of the transcript (Jacobsen \& Peltz 1996). In other cases, deadenylation occurs and may be an obligate event in the decay pathway, but it is not the rate-determining step (Decker \& Parker 1993, Muhlrad et al. 1995).

Shortening of the poly(A) tail by $3^{\prime}-5^{\prime}$ exonucleases is followed by decapping at the $5^{\prime}$ end, which may or may not be a rapid process and is mRNA-specific (Decker \& Parker 1993, Muhlrad et al. 1995, Imataka et al. 1998). Removal of the 5' cap allows the subsequent entry of exoribonucleases that digest the mRNA in a $5^{\prime}$ to $3^{\prime}$ direction. This has been shown to occur in all eukaryotic organisms studied; examples include mammalian c-fos (Shyu et al. 1991), yeast MFA2 (Muhlrad et al. 1994) and oat phytochrome A (Higgs \& Colbert 1994).

However, 3'-5' exonucleolytic degradation after deadenylation also occurs, as in yeast PGK1 (Muhlrad \& Parker 1994, Muhlrad et al. 1995), oat phytochrome A (Higgs \& Colbert 1994) and mammalian c-myc (Brewer 1999) mRNAs. Ford et al. (1997) determined that the presence of a poly(A) tail of at least 30 nucleotides prevented $3^{\prime}-5^{\prime}$ degradation by blocking the assembly, but not the action, of an exonuclease. This effect was shown to be position dependent, as placing a poly(A) sequence internal to the $3^{\prime}$ end destabilized the transcript, without altering its interaction with poly(A) binding protein (PABP) (see below). There is growing evidence to support $3^{\prime}-5^{\prime}$ decay. Most significantly, in vivo and in vitro studies by Brewer (1999) recently demonstrated that the $3^{\prime}-5^{\prime}$ decay pathway contributed to the turnover of c-myc mRNA. Thus, the $3^{\prime}-5^{\prime}$ decay pathway may represent a major turnover pathway in mammalian cells, resulting in a major paradigm shift for those working in the field of mRNA decay.

Deadenylation-independent decapping by decapping protein 1 (Dcp1) occurs in mRNAs that contain nonsense codons (Hagan et al. 1995). This process is considered to be a translation-related event that allows exoribonuclease entry to the mRNA and subsequent digestion of the message (Jacobson \& Peltz 1996). This mechanism exists in eukaryotes mainly to ensure that aberrant mRNAs are not translated, but is also related to the degradation process initiated in non-aberrant mRNAs that all contain stop codons.

\section{Role of sequence elements}

The differences in decay rates in stable and unstable $\mathrm{mRNAs}$ are attributable to the presence or absence of specific sequence elements. With the exception of the stabilizer sequences that appear to be associated with the yeast PGK1 mRNA (Heaton et al. 1992, Peltz et al. 1993) and the human $\alpha$-globin mRNA (Weiss \& Liebhaber 1995), all identified elements promote mRNA destabilization. These sequences include the well characterized adenosine (A)+ uridine (U)-rich elements (AREs) located in the $3^{\prime} \mathrm{UTR}$ s of mammalian mRNAs, in addition to other sequences in mRNA coding regions, $3^{\prime} \mathrm{UTR}$ and $5^{\prime}$ UTRs.

AU-rich elements (AREs) In 1986, Shaw \& Kamen observed that an ARE in the 3'UTR of granulocyte-macrophage colony-stimulating factor (GM-CSF) mRNA could stimulate the degradation of the normally stable $\beta$-globin mRNA. Similarly, the $3^{\prime} \mathrm{UTR}$ of $\mathrm{c}-\mathrm{fos}$, which contains a $69 \mathrm{nt}$ ARE, reduced the stability of $\beta$-globin mRNA (Chen \& Shyu 1995, Chen et al. 1995). Subsequently, AREs that function as RNA destabilizing elements have been found in numerous mRNAs, including c-myc, junB, nur77, $\beta$-interferon, interleukin (IL)-1 $\alpha$ and IL-3 mRNAs (Cleveland \& Yen 1989, Chen \& Shyu 1994, 1995, Gorospe \& Baglioni 1994). The sequence consensus for the ARE is loosely defined as a pentamer comprising AUUUA, repeated once or several times within the $3^{\prime} \mathrm{UTR}$. It is often found within a U-rich region of the mRNA. However, recent work has suggested that a nonamer, UUAUUUA(U/A)(U/A), is more indicative of rapid destabilization (Lagnado et al. 1994, Zubiaga et al. 1995). It is now becoming clear that it is the combination of functionally and structurally distinct sequence motifs, such as AU-pentamers, nonamers and U-rich stretches, that determines the ultimate destabilizing ability of each particular ARE.

Other $3^{\prime}$ UTR elements associated with poly(A) tail shortening There is a growing number of non-ARE 3 'UTR instability elements associated with poly(A) tail shortening. Two wellcharacterized cis elements have been identified within the $3^{\prime} \mathrm{UTR}$ s of the ribonucleotide reductase R1 and R2 mRNAs (Chen et al. 1993, Amara et al. 
1995, Fan et al. 1996); regulation of expression of $\mathrm{R} 2$ is especially important in tumorigenesis. R1 and R2 mRNAs contain sequences within their $3^{\prime} \mathrm{UTR}$ that are bound by the specific proteins $\mathrm{R} 1 \mathrm{BP}$ and R2 BP, respectively (Chen et al. 1993, Amara et al. 1995). Increased binding of these RNA-binding proteins leads to accelerated R1/R2 mRNA decay (Amara et al. 1995, Fan et al. 1996). Interestingly, tumorigenesis was associated with decreased binding of $\mathrm{R} 1 \mathrm{BP}$ and $\mathrm{R} 2 \mathrm{BP}$ to their respective cognate 3'UTR mRNA sequences, which resulted in overexpression of R1 and R2 proteins.

Coding region elements Destabilizing sequences are not limited to the $3^{\prime} \mathrm{UTR}$ and can be found throughout the mRNA. The open reading frame (ORF) of $\beta$-tubulin contains an $N$-terminal tetrapeptide that provides a signal for rapid decay of the mRNA when tubulin monomer is in excess (Yen et al. 1988). Similarly, the c-fos mRNA contains a second destabilizing sequence within the ORF; however, it is only utilized when the message is transiently expressed after growth factor stimulation (Shyu et al. 1989). In addition, c-myc has a cis element located within the coding region (Shyu et al. 1989).

\section{Endonuclease mRNA decay: poly(A) tail-independent degradation}

Deadenylation-independent endonuclease degradation of certain mRNAs does occur and cleavage sites have been identified in the $3^{\prime}$ UTRs and coding regions of a small number of mRNAs. Examples of transcripts that undergo degradation by this method include mammalian 9E3 (Stoekle \& Hanafusa 1989), insulin-like growth factor-II (Nielson \& Christiansen 1992), transferrin receptor (TfR) (Binder et al. 1989, 1994) and Xenopus Xihbox2B (Brown et al. 1993) mRNAs. Sequence-specific endonuclease target sites are likely to be limited to individual mRNAs or classes of mRNAs, and their presence probably allows for specific control of the decay rates of these particular transcripts.

Endonucleolytic cleavage of some of these mRNAs is regulated by RNA-binding proteins that bind in the vicinity of the cleavage site that renders the site inaccessible to nucleolytic attack. One of the most studied examples is the iron-responsive element (IRE) within the TfR mRNA, in which decay is regulated, not only in response to cellular iron concentrations, but to multiple stimuli (Klausner et al. 1993, Leedman et al. 1996, Posch et al. 1999, Thomson et al. 1999a). The 3'UTR of this mRNA contains five distinct stem-loop structures capable of binding the IRE-binding protein (iron-regulatory protein, IRP) (see below). Conditions that favor binding of the IRP lead to stabilization of the mRNA sequence as it protects the functional cleavage site between two of the IREs (Lok \& Ponka 1999, Posch et al. 1999). Destabilization of the TfR mRNA occurs in conditions that favor a reduction of IRP affinity for the TfR IREs (Fig. 3).

Endonucleolytic cleavage of some mRNAs is dependent upon current translation, and this may reflect ribosome displacement of bound RNAbinding proteins in the coding region, the melting of secondary structures that leads to exposure of linear sequences, or accumulation of specific endonucleases (Jacobsen \& Peltz 1996, Deo et al. 1999). Deadenylation or endonucleolytic cleavage may be two independent means of disrupting RNA-protein complexes and creating substrates for exonucleases responsible for the bulk of mRNA degradation.

\section{CYTOPLASMIC MRNA: TRANS-ACTING RNA-BINDING PROTEINS}

Realization of the complexity of cis elements led to the development of assays to detect RNA-binding proteins targeting these regions. Development of the RNA electrophoretic mobility shift assay (REMSA) and u.v. cross-linking assay (Liebold \& Munro 1988, Wilson \& Brewer 1999, Thomson et al. 1999b), which involve the incubation of a radiolabeled RNA probe with cell protein extract, transformed investigation in this area. With these assays, specific RNA-protein interactions were readily detected, the effects of various treatments easily discerned, and the size of the proteins determined. Identification of specific proteins was made with the addition of specific antibodies that supershift the protein band in a REMSA. Using these approaches, regulated RNA-binding proteins have been characterized in the pituitary that target several different mRNAs, including TSH $\beta$ and thyrotropin-releasing hormone receptor (TRHR) mRNAs. In the past several years, a vast array of proteins has been described that bind to various mRNA sequences implicated in mRNA destabilization. However, to date, few of these proteins have been shown to play a definite role in modulating mRNA turnover. Identification and cloning of some of these protein factors has provided enormous insight into the mechanisms involved in regulated mRNA turnover. 


\section{Ferritin mRNA 5'UTR}

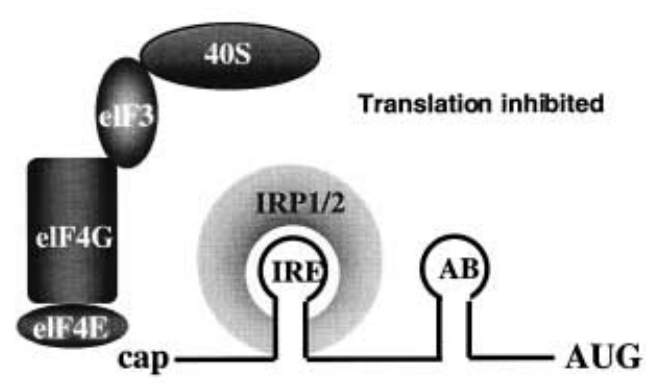

Translation uninhibited

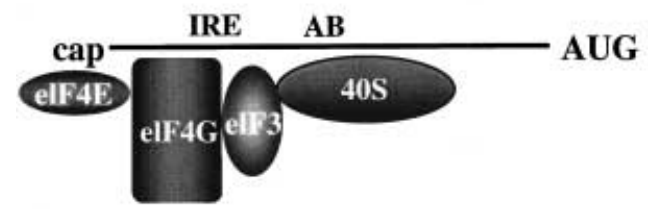

Transferrin receptor mRNA 3'UTR
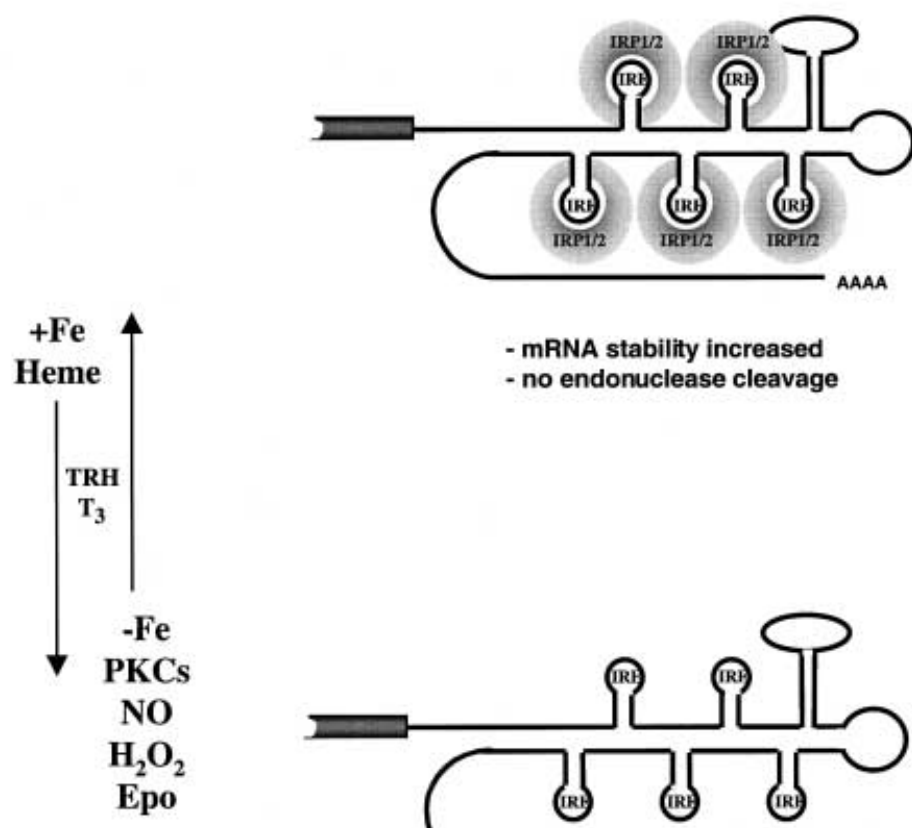

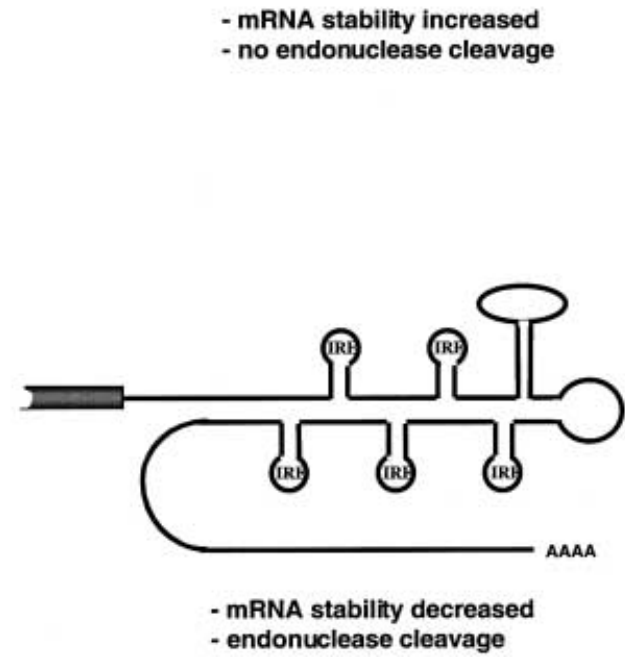

- mRNA stability increased

- endonuclease cleavage

FIGURE 3. Posttranscriptional regulation of ferritin and TfR mRNAs by interactions of IRPs 1 and 2 with IRE. IRP1 and IRP2, when bound to the 5'UTR IRE of ferritin mRNA, block the binding of the ribosomal initiation complex and inhibit translation. The binding of an uncharacterized RBP to the acute box (AB) stem-loop also plays a role in translational initiation. Both stem-loop structures may be important for steric presentation of the mRNA to the initiation complex. (Interaction of poly(A) tail and associated proteins in translation is not shown in this diagram.) When IRPs 1 and 2 are bound to the five IREs in the TfR mRNA 3'UTR, they block endonuclease attack, which results in an increase in TfR mRNA stability. Thyrotropin-releasing hormone (TRH) and tri-iodothyronine $\left(\mathrm{T}_{3}\right)$ can increase or decrease IRP1 and IRP2 binding activity to the ferritin IRE, depending on the cell type. PKCs, protein kinases C; Epo, erythropoietin.

\section{Poly(A) binding protein (PABP)}

PABP is a highly conserved $71 \mathrm{kDa}$ protein found in the cytoplasm and nucleus that binds to the poly(A) tail with high affinity and plays an important part in regulating its length (Blobel 1973, Baer \& Kornberg 1983, Bernstein et al. 1989, Jackson \& Standart 1990, Munroe \& Jacobson 1990, Görlach et al. 1994, Smith et al. 1997, Afonina et al. 1998, Deo et al. 1999). PABP contains four RNA-recognition motifs (RRMs 1-4) and a proline-rich carboxy terminus (Burd et al. 1991, Deo et al. 1999). The cocrystal structure of human PABP with poly(A) was recently determined (Deo et al. 1999). RRM1 and RRM2 are responsible for poly(A) binding (Deo et al. 1999), but RRM4 is mainly involved in non-specific polypyrimidine RNA binding (Smith et al. 1997). Recent studies have shown that PABP is also able to bind to AU-rich stretches of mRNA (Afonina et al. 1997). Interestingly, RNA binding, but not high-affinity poly(A) binding, is correlated with the ability of PABP to sustain yeast viability (Sachs et al. 1987), reinforcing the notion that PABP plays a major role in regulating mRNA stability, independently of its role in poly(A) length regulation (Caponigro \& Parker 1995, Deardoff \& Sachs 1997, Craig et al. 1998, Deo et al. 1999).

mRNA stabilization by PABP requires current translation of the mRNA, and PABP preferentially stabilizes mRNAs the decay of which is deadenylation-dependent, with little or no effect on mRNAs that decay independently of deadenylation 
(Coller et al. 1998). A model has been postulated in which PABP acts to hold both ends of an mRNA in close proximity. PABP does interact in vitro with the translation initiation factors eIF4 G, eIF4F and eIF4B in plants and yeast, both in the presence and the absence of poly(A) RNA (Le et al. 1997, Tarun \& Sachs 1996, Gallie 1998). In humans, eIF4 G has recently been shown to bind to PABP (Imataka et al. 1999). This interaction inhibits poly(A)dependent translation, but has no effect on translation of deadenylated mRNA (Imataka et al. 1999). Mammalian PABP also binds to PABPinteracting protein-1 (PAIP-1) (Craig et al. 1998). PAIP-1 shares $25 \%$ homology with a 470 amino acid region of mammalian eIF4 G. Remarkably, increasing the concentration of PAIP-1 in vivo resulted in a modest $2 \cdot 8$-fold increase in translation in COS-7 cells (Craig et al. 1998), suggesting an important role for this protein in the regulation of translational efficiency (Deo et al. 1999).

\section{AU-rich element binding proteins (AUBPs)}

A family of proteins has been characterized by REMSA that bind to AU-rich, and sometimes U-rich RNAs with high affinity. In most cases, binding of these AUBPs (30-45 kDa) increases the turnover of ARE-containing mRNAs (DeMaria \& Brewer 1996, Joseph et al. 1998).

\section{The elav-like proteins}

One of the best characterized AUBPs is HuR, a $36 \mathrm{kDa}$ member of the embryonic lethal abnormal vision (elav) family of RRM-containing RNAbinding proteins (Levine 1993, Joseph et al. 1998). The elav-like protein family contains four proteins, namely HuC, Hel-N1, HuD and HuR (Myer et al. 1997). HuR has been shown to bind with high affinity to ARE sequences (Levine 1993, Joseph et al. 1998). Most importantly, HuR has an active role in the stabilization of specific mRNAs containing AREs, such as glucose transporter 1, c-fos, GM-CSF, plasminogen activator inhibitor type 2 and p21 waf1 (Jain et al. 1997, Levy et al. 1998, Fan \& Steitz 1998, Maurer et al. 1999, Joseph et al. 1998). The ability of elav/Hu proteins to stabilize ARE-containing mRNAs was confirmed recently using an in vitro system (Ford et al. 1999). Interestingly, HuR appears to shuttle between the nucleus and the cytoplasm, and it has been postulated that this function is to chaperone AREs out to the cytoplasm (Fan \& Steitz 1998). Aberrant shuttling may therefore render the ARE susceptible to decay in the cytoplasm. HuR may also have an effect at the translational level, coupling mRNA stability and translation, an association studied extensively by Jacobson \& Peltz (1996).

\section{AU-binding factor 1 (AUF1)}

The proto-oncogene, c-myc, contains ARE sequences in the $3^{\prime} \mathrm{UTR}$ of its mRNA. These sequences act as destabilizing elements and bind the RNA-binding protein, AUF1 (Brewer 1991, Zhang et al. 1993, DeMaria et al. 1997, Wilson \& Brewer 1999, Wilson et al. 1999). AUF1 has been implicated in the regulation of many cytokine and $\mathrm{G}$ protein-coupled receptor mRNAs (Wilson \& Brewer 1999), and plays a major role in development (Lafon et al. 1998). Different splice variants of AUF1 exist and all bind to ARE sequences. The 37 and $40 \mathrm{kDa}$ isoforms are found throughout the cell, whereas the p42 and p45 isoforms reside only in the nucleus (Wilson \& Brewer 1999). Interestingly, four $3^{\prime}$ UTR splice variants also exist that alter expression of AUF1 (Wilson et al. 1999). AUF1 contains two non-identical RRMs that interact with other sequences within the protein structure to facilitate RNA-binding (Wilson \& Brewer 1999). AUF1 is also known to bind to eIF4 G and PABP. AU-rich mRNA decay is associated with displacement of eIF4 G from AUF1, ubiquitination of AUF1 and degradation of AUF1 by proteasomes (Laroia et al. 1999).

\section{Other ARE binding proteins}

An intriguing finding has been the isolation of glyceraldehyde-3-phosphate dehydrogenase (GAPDH) and enoyl coenzyme A (CoA) hydratase from ARE-binding protein screens (Nagy \& Rigby 1995, Wilson \& Brewer 1999). These proteins contain ARE-binding motifs, but their significance in RNA turnover has yet to be established.

\section{Non-ARE-binding proteins}

Reports characterizing novel non-ARE RNAbinding proteins are increasing, although we shall focus on the most studied of these proteins, the IRPs. Two mammalian isoforms exist, IRP1 and IRP2, IRP1 acting as a cytoplasmic aconitase under conditions favoring low-affinity mRNA binding (Klausner et al. 1993, Leedman et al. 1996, Thomson et al. 1999a).

Posttranslational modification of IRP1 and IRP2 alters their binding affinity for their specific cognate mRNA hairpin structures, the IREs, and controls the expression of genes posttranscriptionally. IREs present in the $5^{\prime} \mathrm{UTR}$ of ferritin, erythroid 5 -aminolevulinate synthase and mammalian mitochondrial aconitase mediate the translational efficiency of these mRNAs (Klausner et al. 1993, 
TABLE 1. Summary of non-pituitary-derived genes that are known to be regulated by hormones

\section{Regulation}

\section{mRNA affected}

Vitellogenin

ApoVLDII

Ovalbumin

Conalbumin

$\mathrm{MCH}$

Proteolipid protein

HMG-CoA reductase

NADH dehydrogenase subunit 3

Vasopressin

PAM

$\mathrm{CRH}$

Inhibin $\alpha$

Renin

Malic enzyme

FSHR

Casein

PR

TRHR

$\mathrm{LH} / \mathrm{hCGR}$

FSHR

AR

EGFR
mRNA stabilized 30-fold by estrogen

mRNA stabilized and poly(A) tail increased by estrogen

mRNA stabilized by estrogen or progesterone

mRNA stabilized by estrogen or progesterone

mRNA stabilized by lithium

mRNA stabilized 10-20-fold by retinoic acid

mRNA stabilized twofold by $\mathrm{T}_{3}$

mRNA stabilized threefold by $\mathrm{T}_{3}$; mRNA

destabilized five- to sixfold by Dex or hydrocortisone

mRNA stabilized 20-fold by ACTH

mRNA stabilized by dehydration through increased poly(A) tail length

mRNA destabilized by estrogen

mRNA stabilized 16-fold and poly(A) tail length

increased by protein kinase $\mathrm{C}$

mRNA stabilized by cAMP

mRNA stabilized three- to fourfold by cAMP

mRNA stabilized twofold by $\mathrm{T}_{3}$

mRNA stabilized $1.5-2$-fold by activin

mRNA stabilized 20 -fold by prolactin

mRNA stabilized by LH or FSH

mRNA destabilized by TRH

mRNA destabilized threefold by LH

mRNA stabilized sixfold by FSH

mRNA stabilized by DHT

mRNA stabilized by EGF
Reference

Brock \& Shapiro (1982)

Cochrane \& Deely (1988)

Cox (1977)

McKnight \& Palmiter (1979)

Presse et al. (1997)

Lopez-Barahona et al. (1993)

Simonet \& Ness (1989)

Raikhinstein \& Hanukoglu (1993)

Zingg et al. (1988) Robinson et al. (1988)

El Meskini et al. (1997)

Adler et al. (1992)

Najmabadi et al. (1993)

Chen et al. (1993)

Song et al. (1988)

Tano et al. (1997)

Guyette et al. (1979)

Iwai et al. (1991)

Fujimoto et al. (1992b)

Lu et al. (1993)

Tilly et al. (1992)

Yeap et al. (1999)

McCulloch et al. (1998)

apoVLDII, Very-low-density lipoprotein II; MCH, melanin concentrating hormone; PAM, peptidyl-glycine $\alpha$-amidating mono-oxygenase; CRH, corticotropin releasing hormone; PR, progesterone receptor; LH/ hCGR, luteinizing hormone/human chorionic gonadotropin-receptor; AR, androgen receptor; DHT, dihydro-testosterone; Dex, dexamethasone.

Thomson et al. 1999a). IREs present in the 3'UTR of the TfR mediate mRNA stability (Posch et al. 1999). This coordinate but divergent posttranscriptional regulation of IRP/IRE RNA-protein interactions governs iron homeostasis by modulating target gene expression posttranscriptionally. Interestingly, the binding affinity of IRP1 and IRP2 is modulated by various hormones, including thyroid hormone (tri-iodothyronine, $\mathrm{T}_{3}$ ) (Leedman et al. 1996), TRH (Thomson et al. 1999a), and erythropoietin (Weiss et al. 1997).

\section{HORMONE-REGULATED MRNA TURNOVER}

As outlined below, the targets for the hormones that influence pituitary and non-pituitary mRNA stability are distributed widely and involve endocrine and non-endocrine organs (Table 1). For example, several hormones influence the mRNA stability of their own receptor in a feedback regulation mechanism (Table 1). In many cases, hormones regulate expression at transcriptional, posttranscriptional and posttranslational levels of their target genes.

\section{Hormonal regulation of non-pituitary gene mRNA stability}

Steroid hormones were one of the earliest agents shown to control the degradation of specific mRNAs and to regulate the stability of a substantial number of mRNAs. The best characterized is the stabilization of vitellogenin mRNA by estrogen (Nielsen \& Shapiro 1990a). Vitellogenin mRNA levels increase $>10000$-fold upon estrogen stimulation in Xenopus liver (Brock \& Shapiro 1982, 1983). The estrogen-mediated increase in vitellogenin mRNA is effected by an increase in both transcription and mRNA stability (Brock \& Shapiro 1982, 1983). The mRNA half-life of hepatic vitellogenin increases from $16 \mathrm{~h}$ to $500 \mathrm{~h}$ after the administration of estrogen (Brock \& Shapiro 1983). Further analysis revealed that an estrogen-regulated cis-acting element was situated in the 3'UTR of vitellogenin mRNA (Nielsen \& Shapiro 1990b), and required association of the $\mathrm{mRNA}$ with ribosomes for stabilization (Blume \& Shapiro 1989).

More recently, a polysome-associated protein of molecular mass $150-155 \mathrm{kDa}$ was shown to bind 
specifically within a $27 \mathrm{nt}$ region of a $94 \mathrm{nt}$ segment (required for maximal binding) of the $3^{\prime} \mathrm{UTR}$ of vitellogenin mRNA in an estrogen-inducible manner (Dodson \& Shapiro 1994, 1997, Dodson et al. 1995, Kanamori et al. 1998). This protein has subsequently been identified as vigilin. It is ubiquitously expressed and contains 14 human ribonucleo protein $\mathrm{K}$ (hnRNPK) homology $(\mathrm{KH})$ domains and had previously been shown to bind tRNA (Kruse et al. 1996). The $14 \mathrm{KH}$ domains in vigilin allow its interaction with multiple mRNAs that contain specific, mainly single stranded, regions that constitute long RNA binding sites ( $\sim 75 \mathrm{nt}$, (A) ${ }_{n} \mathrm{CU}$ and $\mathrm{UC}(\mathrm{A})_{n}$ motifs) (Kanamori et al. 1998); its association with other proteins may also define binding specificity or cytoplasmic targeting. Vigilin is present in both the cytoplasm and the nucleus of cells (Kugler et al. 1996), and may be involved in shuttling of mRNAs from nucleus to cytoplasm. A clear functional role of RNA binding of vigilin has not been established (Kanamori et al. 1998), but its estrogen-regulated binding to vitellogenin mRNA and associated increase in vitellogenin mRNA stability emphasize its importance in regulating mRNA metabolism.

Other hormones known to influence posttranscriptional events include $\mathrm{T}_{3}$, which increases the stability of 3-hydroxy-3-methylglutaryl CoA (HMG-CoA) reductase mRNA approximately threefold (Simonet \& Ness 1989). This stabilization was blocked by hydrocortisone and dexamethasone, each of which reduced the stability of HMG-CoA reductase mRNA five- to sixfold (Simonet $\&$ Ness 1989). More recently, $T_{3}$ was shown to increase the stability of proteolipid (the major component of myelin) mRNA approximately twofold. Interestingly, retinoic acid induced a $\sim 10$-fold increase in proteolipid mRNA stability in C6 glioma cells (Lopez-Barachona et al. 1993). Other effects of $\mathrm{T}_{3}$ include the stabilization of malic enzyme $\mathrm{mRNA}$ in rat liver (Back et al. 1986, Song et al. 1988).

The ovary and adrenals are also sites at which hormonal regulation of mRNA stability has been observed. Treatment of ovarian granulosa cells with $\mathrm{LH}$ or $\mathrm{FSH}$ for $3 \mathrm{~h}$ increased progesterone receptor mRNA eight- to ninefold (Iwai et al. 1991). Incubation of adrenal cortex cells with ACTH stabilized mitochondrial mRNA (Raikhinstein \& Hanukoglu 1993) and also NADH dehydrogenase subunit $3 \mathrm{mRNA}$, increasing the latter mRNA approximately 20 -fold after $6 \mathrm{~h}$ of exposure.

An increasing number of hormones have been shown to regulate expression of their own receptor at the posttranscriptional level. For example, the stability of the epidermal growth factor receptor (EGFR) mRNA was increased more than threefold by EGF and by transforming growth factor $\alpha$ $(\mathrm{TGF} \alpha)$ in epidermoid cancer cells (McCulloch et al. 1998), and approximately twofold by EGF and TGF $\alpha$ in prostate cancer cells (Seth et al. 1999). Recent studies utilizing prostate cancer LNCaP cells showed that androgens (dihydro-testosterone) increased the stability of the androgen receptor mRNA approximately twofold (Yeap et al. 1999). Finally, the TRHR mRNA is destabilized by TRH in pituitary cells (Narayan et al. 1992).

\section{Hormonal regulation of pituitary gene mRNA stability}

A large number of genes expressed in the pituitary are regulated at the level of mRNA stability (Table $2)$. For example, mRNA stability of the common $\alpha$-glycoprotein subunit was recently compared with that of LH $\beta$ and FSH $\beta$ mRNAs (Bouamoud et al. 1992). Interestingly, there was broad variation in the basal half-life for each mRNA, with values of $1 \cdot 0,6 \cdot 5$ and $44 \mathrm{~h}$ for $\mathrm{FSH} \beta$, the $\alpha$-subunit and $\mathrm{LH} \beta$ mRNAs, respectively. Rapid disappearance of these mRNAs was associated with a progressive shortening of the poly(A) tail (Bouamoud et al. 1992). In addition, the stability of each of these mRNAs was regulated extrinsically by various ligands. For example, the mRNA stability of the $\alpha$-subunit was increased six- to sevenfold in the presence of gonadotropin releasing hormone $(\mathrm{GnRH})$ in $\alpha \mathrm{T}_{3}$ pituitary cells (Chedrese et al. 1994). Similarly, GnRH stabilized LH $\beta$ mRNA, and this stabilization was further augmented by progesterone, or a combination of estrogen and progesterone (Park et al. 1995). Interestingly, FSH $\beta$ subunit mRNA, but not $\alpha$-subunit or LH $\beta$ mRNA, was stabilized by testosterone in male rat gonadotropes (Paul et al. 1990). In a separate study, estrogen was shown to increase the mRNA stability of another pituitary hormone receptor, TRHR, approximately twofold in rat pituitary primary cultures (Kimura et al. 1994).

We and others have shown that TSH $\beta$ subunit mRNA is regulated posttranscriptionally by $\mathrm{T}_{3}$, reducing its half-life from $24 \mathrm{~h}$ to approximately $8 \mathrm{~h}$ in both rat and murine pituitary cells (Krane et al. 1991, Staton \& Leedman 1998). This reduction in mRNA stability was accompanied in both species with a reduction in the length of the poly(A) tail from $160-180$ to $\sim 30$ nt. TSH $\beta$ mRNA was also destabilized by bromocryptine, which reduced the half-life approximately twofold (Levy \& Lightman 1990).

The effect of $\mathrm{T}_{3}$ on the posttranscriptional regulation of $\mathrm{GH}$ expression has been studied extensively by several groups. $\mathrm{T}_{3}$ destabilized and 
TABLE 2. Summary of pituitary-derived genes that are known to be regulated by hormones

\section{Regulation}

mRNA affected

TRHR

$\operatorname{TSH} \beta$

$\mathrm{FSH} \beta$

$\mathrm{GH}$

$\mathrm{LH} \beta$

$\alpha$-subunit

by Dex $+\mathrm{T}_{3}$;
mRNA stabilized twofold by estrogen

mRNA destabilized three- to fourfold and poly(A) tail shortened by $\mathrm{T}_{3}$;

mRNA destabilized twofold by bromocryptine

mRNA stabilized twofold by testosterone

mRNA stabilized and poly(A) tail length increased by glucocorticoids;

mRNA stabilized twofold by $\mathrm{T}_{3}$

mRNA stabilized 50-fold and poly(A) tail length increased

mRNA stabilized by GnRH; GnRH-induced mRNA

stability augmented with progesterone or

progesterone + estrogen

mRNA stabilized six- to sevenfold by GnRH
Reference

Kimura et al. (1994)

Staton \& Leedman (1998)

Levy \& Lightman (1990)

Paul et al. (1990)

Paek \& Axel (1987)

Diamond \& Goodman (1985)

Jones et al. (1990)

Park et al. (1995)

Chedrese et al. (1994)

Dex, Dexamethasone.

deadenylated GH mRNA in rat pituitary cells (Murphy et al. 1992). However, when $\mathrm{T}_{3}$ was combined with dexamethasone, a 50 -fold increase in GH mRNA was observed, predominantly as a result of stabilization of the mRNA associated with an increase in the length of the poly(A) tail (Diamond \& Goodman 1985, Paek \& Axel 1987, Jones et al. 1990).

There are abundant examples of pituitary ligands regulating the mRNA stability of their own receptor in non-pituitary tissue. LH decreased the stability of $\mathrm{LH} / \mathrm{hCG}$-receptor mRNA approximately threefold in rat ovary primary cultures (Lu et al. 1993). The stability of FSH- and activin-stabilized FSH receptor (FSHR) mRNA is increased several-fold in ovarian granulosa cells (Tilly et al. 1992, Tano et al. 1997). Recent studies identified an LH receptor mRNA stability LH-receptor RNA-binding protein (LRBP-1) of molecular mass $50 \mathrm{kDa}$ that bound to a $180 \mathrm{nt}$ region within the ORF of $\mathrm{LH}$ receptor mRNA (Kash \& Menon 1998). Moreover, the binding of LRBP-1 increased approximately threefold after $12 \mathrm{~h}$ of incubation with LH (Kash \& Menon 1998).

Very little is known about posttranscriptional regulation of gene expression in the posterior pituitary. In 1988, Zingg et al. observed that dehydration caused an increase in the poly(A) tail length of vasopressin (from $210 \mathrm{nt}$ to $330 \mathrm{nt}$ ), associated with increased mRNA stability. Robinson et al. (1988) investigated this further and determined that the variation in length occurred in the suprachiasmatic hypothalamic nuclei, the location of an endogenous mammalian circadian pacemaker. These results suggested that the variation in mRNA poly(A) tail length may underlie the circadian

www.endocrinology.org rhythm of vasopressin peptide levels in cerebrospinal fluid (Robinson et al. 1988).

In summary, the regulation of expression of hormones secreted by the pituitary has been studied extensively, the vast proportion being regulated, in part, at the level of mRNA stability. However, the mechanisms underlying these changes in mRNA turnover for the majority of these genes remain largely unknown.

\section{Hormonal regulation of RNA-protein interactions and mRNA decay in the pituitary}

There are a few examples of regulated mRNA decay in the pituitary for which RNA-protein interactions have been more clearly defined.

\section{Posttranscriptional regulation of TSH $\beta$ mRNA expression}

Several studies have shown that $\mathrm{T}_{3}$ decreases TSH $\alpha$ - and TSH $\beta$-subunit steady-state mRNA levels, in part as a result of reduced transcription (Surks \& Litschitz 1977, Ross et al. 1983, Shupnik et al. 1985). TSH $\beta$ mRNA is also regulated by $\mathrm{T}_{3}$ at the posttranscriptional level, accompanied by a shortening of the poly(A) tail (Krane et al. 1991, Staton \& Leedman 1998). In the presence of actinomycin $\mathrm{D}$, but the absence of $\mathrm{T}_{3}$, TSH $\beta$ mRNA was deadenylated without inducing rapid mRNA decay, suggesting that deadenylation alone was not sufficient for the acceleration of TSH $\beta$ mRNA turnover.

We recently isolated a cis-acting element located within the $70 \mathrm{nt}$ of the $3^{\prime} \mathrm{UTR}$ of TSH $\beta$ mRNA (unpublished observations). This sequence does not 


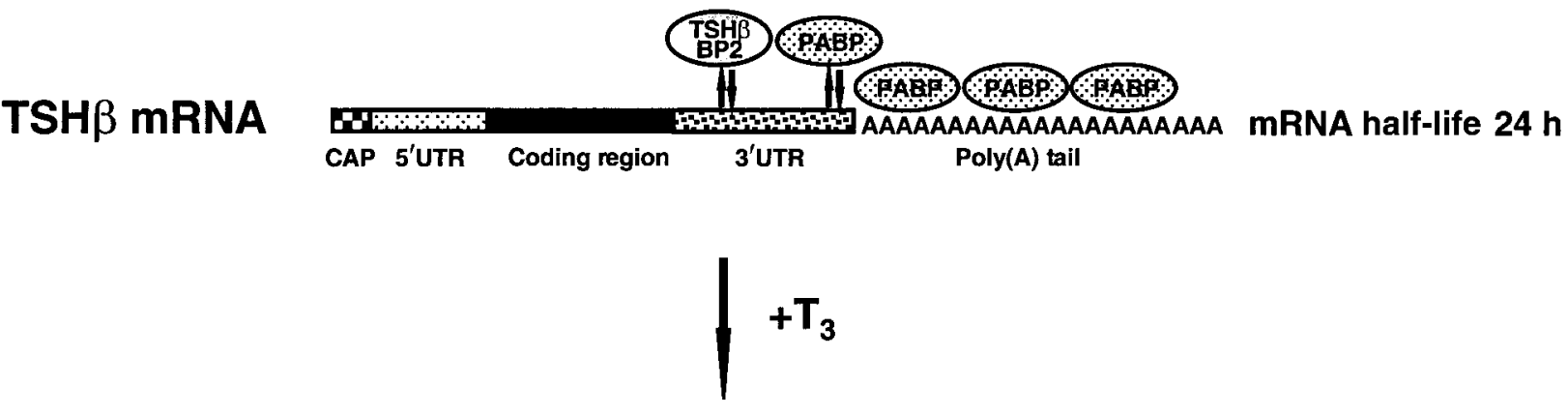

\section{mRNA decay}

TSH $\beta$ mRNA

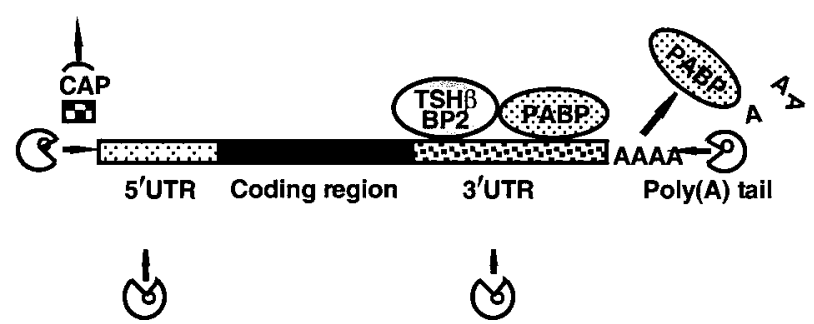

mRNA half-life $7 \mathrm{~h}$

FIGURE 4. Schematic model of $\mathrm{T}_{3}$-mediated decay of TSH $\beta$ mRNA in pituitary cells. In the absence of $\mathrm{T}_{3}$, TSH $\beta$ mRNA is polyadenylated and stable; in the presence of $\mathrm{T}_{3}$, it is deadenylated and undergoes decay by exonucleases and/or endonucleases. $T_{3}$ regulates binding of $3^{\prime} \mathrm{UTR}$ mRNA-binding proteins, PABP and TSH $\beta$ BP2, which play a role in facilitating TSH $\beta$ mRNA decay.

contain any AREs or other well characterized cis-acting destabilizing elements (Leedman et al. 1995). Interestingly, it was the target for $\mathrm{T}_{3}$ regulated cytoplasmic RNA-binding proteins derived from murine thyrotrope cells. U.v. crosslinking assays identified two major TSH $\beta$ mRNA specific RNA-binding complexes (TSH $\beta$ BP1 and $\mathrm{BP} 2)$ of molecular mass $\sim 60$ and $\sim 72 \mathrm{kDa}$ (unpublished observations). Remarkably, we demonstrated that the $72 \mathrm{kDa}$ complex contained PABP. A proposed model in which $\mathrm{T}_{3}$ coordinately regulates the shortening of the poly(A) tail and the activity of RNA-binding proteins binding specifically to the cis-acting element within the $3^{\prime} \mathrm{UTR}$ of TSH $\beta$ mRNA is illustrated in Fig. 4. The role of PABP in this process is still being elucidated. However, our findings suggest a novel dual role for PABP in the deadenylation and accelerated decay of TSH $\beta$ mRNA, by its ability to bind poly(A) and non-poly(A) sequences, respectively. Cloning and characterization of the other TSH $\beta$ mRNA RNAbinding protein(s) will facilitate careful functional analysis of the role of each protein in regulated TSH $\beta$ mRNA decay, and provide considerable insight into the mechanisms of action of $\mathrm{T}_{3}$ at the posttranscriptional level.
Posttranscriptional regulation of TRHR $m R N A$

Posttranscriptional regulatory mechanisms have been shown to have a critical role in the regulation of TRHR gene expression (Fujimoto et al. 1992a, $b)$. Several actinomycin D chase experiments have shown that TRH regulates TRHR gene expression at the level of mRNA turnover. Endogenous TRHR mRNA in rat pituitary cells was decreased by TRH, and increased by estradiol ( $\left.\mathrm{E}_{2}\right)$ (Kimura et al. 1994). In rat pituitary cells stably transfected with murine TRHR, TRH destabilized TRHR mRNA (Fujimoto et al. 1992a). A cell free mRNA decay assay showed that TRH regulated RNase activity in rat pituitary $\mathrm{GH} 3$ cells, governed by specific sequences within the $3^{\prime}$ UTR of TRHR mRNA (Narayan et al. 1992). In deletion studies, a truncated form of the TRHR missing the entire 3'UTR $(\sim 2 \mathrm{~kb})$ was more stable than the fulllength receptor. Interestingly, deletion of the last $143 \mathrm{nt}$ from the $3^{\prime} \mathrm{UTR}$, which formed a stable stem-loop structure, prevented TRH from enhancing TRHR mRNA decay (Narayan et al. 1992). Thus the TRHR 3'UTR appears to contain two distinct regions. One, the stem-loop at the $3^{\prime}$ end of the $3^{\prime} \mathrm{UTR}$, is necessary for conferring TRHregulated TRHR mRNA degradation. The other, 
which is less well defined, comprises a cis-acting element responsible for TRH-mediated decay. Within this region, there are several AU-rich putative mRNA stability modifying cis-acting regions that are conserved across species. There are four AUUUA pentamers, including one interesting double pentamer, AUUUAUUUA, motif just $5^{\prime}$ to the stem-loop in mouse and rat. We presume that one or more of these AU-rich regions comprise the cis element. Interestingly, the human TRHR 3'UTR $(\sim 0.9 \mathrm{~kb})$ contains many AU-rich regions and a structurally conserved stem-loop at the $5^{\prime}$ end of the $3^{\prime} \mathrm{UTR}$.

We recently identified RNA-binding proteins unique for each of the aforementioned TRHR AU-rich regions and the stem-loop in cytoplasmic extracts from thyrotrope and lactotrope pituitary cells (unpublished observations). Binding activity of these RNA-protein complexes was rapidly upregulated approximately fivefold in both cell types after TRH and phorbol-12 13-myristate acetate stimulation. In marked contrast, however, $\mathrm{T}_{3}$ downregulated binding activity of these $\mathrm{RNA}$-protein complexes. These data provide the first evidence for divergent regulation by TRH and $\mathrm{T}_{3}$ of the binding of these novel RNA-binding proteins to the stem-loop and AU-rich regions of TRHR mRNA. This divergent hormone-regulated change in binding is consistent with the opposing physiologic actions of $\mathrm{T}_{3}$ and $\mathrm{TRH}$ expression in these cell types. Furthermore, these data suggest that a complex system of hormonally regulated RNAprotein interactions is involved in the control of TRHR mRNA decay in the pituitary.

\section{Posttranscriptional regulation of ferritin gene expression in the pituitary}

As alluded to above, control of mammalian intracellular iron homeostasis is largely due to posttranscriptional regulation of binding by IRPs to IREs within ferritin and TfR mRNAs. IRP binding is tightly controlled such that it responds to changes in intracellular iron requirements in a coordinate manner, differentially regulating ferritin mRNA translational efficiency and TfR mRNA stability. Most interestingly, we have found recently that $\mathrm{T}_{3}$ and TRH are capable of modulating the binding of two pituitary IRPs, IRP1 and IRP2, to a ferritin IRE (Thomson et al. 1999a). TRH was found to regulate ferritin protein concentrations similarly in thyrotrope and lactotrope cells but, unexpectedly, differentially modulated the binding of IRP1 and IRP2 to a ferritin IRE. However, $T_{3}$ downregulated IRP binding in both cell types (unpublished observations). TRH induced an increase in IRP binding in thyrotropes, associated with IRP phosphorylation and protein kinase $\mathrm{C}$ (PKC) and mitogen-activated protein kinase (MAPK) activation. However, in lactotropes, TRH decreased IRP binding despite PKC and MAPK activation. These data demonstrate a divergent and cell-specific regulation of IRP binding by TRH and $\mathrm{T}_{3}$ in the pituitary. They also represent a further example of a specific RNA-protein interaction in the pituitary that was divergently regulated by TRH and $\mathrm{T}_{3}$.

These data suggest that multiple RNA-protein interactions may be subject to hormonally divergent regulation in a cell-specific manner. Clearly, we are only just beginning to unravel some of the complexities involved in the fine-tuning of basic cellular functions, such as the control of iron homeostasis. However, this work illustrates the central role that hormones have in the pituitary as regulators of RNA-binding protein binding-activity and intracellular iron concentrations.

\section{CONCLUDING REMARKS}

The main thrust of molecular research in understanding hormone action in the pituitary has, in the past, concentrated on transcriptional regulation and nuclear hormone receptor action. However, it is now evident that mRNA stability and hormonal regulation of $\mathrm{RNA}$-protein interactions within pituitary cells also play a crucial role in regulating pituitary cellular function. Investigations in this field are adding to the global knowledge of RNA-binding proteins, RNA-stability sequences, the role of translation in mRNA stability, mechanisms of RNA degradation, and understanding of the molecular effects of hormone action in the pituitary. The cloning and characterization of novel pituitary RNA-binding proteins will allow, for the first time, a detailed analysis of the impact of these interactions on the vast secretory function of the pituitary gland.

\section{REFERENCES}

Adler GK, Rosen LB, Fiandaca MJ \& Majzoub JA 1992 Protein kinase-C activation increases the quantity and poly(A) tail length of corticotropin-releasing hormone messenger RNA in NPLC cells. Molecular Endocrinology 6 476-484.

Afonina E, Neumann M \& Pavlakis G 1997 Preferential binding of Poly(A) binding protein 1 to an inhibitory RNA element in the human immunodeficiency virus type 1 gag mRNA. Fournal of Biological Chemistry 272 2307-2311.

Afonina E, Stauber R \& Pavlakis G 1998 The human poly(A) binding protein 1 shuttles between the nucleus and the cytoplasm. Fournal of Biological Chemistry 273 13015-13021. 
Amara FM, Hurta RA, Huang A \& Wright JA 1995 Altered regulation of message stability and tumor promoterresponsive cis-trans interactions of ribonucletide reductase $\mathrm{R} 1$ and R2 messenger RNAs in hydroxyurea-resistant cells. Cancer Research 55 4503-4506.

Back DW, Wilson SB, Morris SM \& Goodridge AG 1986 Hormonal regulation of lipogenic enzymes in chick embryo hepatocytes in culture. Fournal of Biological Chemistry 261 12555-12561.

Baer BW \& Kornberg RD 1983 The protein responsible for the repeating structure of cytoplasmic poly(A)-ribonucleoprotein. Fournal of Cellular Biology 96 717-721.

Beelman CA \& Parker R 1995 Degradation of mRNA in eukaryotes. Cell 81 179-183.

Bernstein P, Peltz S \& Ross J 1989 The poly(A)-poly(A)binding protein complex is a major determinant of mRNA stability in vitro. Molecular and Cellular Biology 9 659-670.

Binder R, Hwang S-P, Ratnasabapathy R \& Williams DL 1989 Degradation of apolipoprotein II mRNA occurs via endonucleolytic cleavage at $5^{\prime}$-AAU-3' $/ 5^{\prime}$-UAA-3' elements in single stranded loop domains at the $3^{\prime}$ non-coding region. Fournal of Biological Chemistry 264 16910-16918.

Binder R, Horowitz JA, Basilion JP, Koeller DM, Klausner RD \& Harford JB 1994 Evidence that the pathway of trasferrin receptor $\mathrm{mRNA}$ degradation involves an endonuceolytic cleavage within the 3'UTR and does not involve poly(A) tail shortening. EMBO fournal 13 1969-1980.

Blobel G 1973 A protein of molecular weight 78000 bound to polyadenylate region of eukaryotic messenger RNAs. PNAS 70 924-928.

Blume JE \& Shapiro DJ 1989 Ribosome loading, but not protein synthesis, is required for estrogen stabilization of Xenopus laevis vitellogenin mRNA. Nucleic Acids Research 17 9003-9014.

Bouamoud N, Lerrant Y, Ribot G \& Counis R 1992 Differential stability of mRNAs coding for $\alpha$ and gonadotropin $\beta$ subunits in cultured rat pituitary cells. Molecular and Cellular Endocrinology 88 143-151.

Brewer G 1991 An A+U-rich element RNA-binding factor regulates cmyc mRNA stability in vitro. Molecular and Cellular Biology 11 2460-2466.

Brewer G 1999 Evidence for a 3'-5' decay pathway for $c-m y c$ mRNA in mammalian cells. Fournal of Biological Chemistry 274 16174-16179.

Brock ML \& Shapiro DJ 1982 Estrogen regulates the absolute rate of transcription of the Xenopus laevis vitellogenin genes. Fournal of Biological Chemistry 258 5449-5455.

Brock ML \& Shapiro DJ 1983 Estrogen stabilizes vitellogenin mRNA against cytoplasmic degradation. Cell 34 207-214.

Brown BD, Zipkin ID \& Harland RM 1993 Sequence specific endonucleolytic cleavage and protection of mRNA in Xenopus and Drosophila. Genes and Development 7 1620-1631.

Burd C, Matunis E \& Dreyfuss G 1991 The multiple RNA-binding domains of the mRNA poly(A)-binding protein have different RNA-binding activities. Molecular and Cellular Biology 11 3419-3424.

Caponigro G \& Parker R 1995 Multiple functions for the poly(A)-binding protein in mRNA decapping and deadenylation in yeast. Genes and Development 9 2421-2432.

Chedrese PJ, Kay TWH \& Jameson JL 1994 Gonadotropin-releasing hormone stimulates glycoprotein hormone $\alpha$-subunit messenger ribonucleic acid (mRNA) levels in $\alpha \mathrm{T} 3$ cells by increasing transcription and mRNA stability. Endocrinology 134 2475-2481.

Chen C \& Shyu A 1994 Selective degradation of earlyresponse-gene mRNAs: functional analysis of sequence features of the AU-rich elements. Molecular and Cellular Biology 14 8471-8482.

Chen C \& Shyu A 1995 AU-rich elements: characterization and importance in mRNA degredation. Trends In Biochemical Science 20 465-470.

Chen FY, Amara FM \& Wright JA 1993 Mammalian ribonucleotide reductase R1 mRNA stability under normal and phorbol ester stimulating conditions: involvement of a cis-trans interaction at the $3^{\prime}$ untranslated region. EMBO Fournal 12 3977-3986.

Chen C, Xu N \& Shyu A 1995 mRNA decay mediated by two distinct AU-rich elements from c-fos and granulocytemacrophage colony-stimulating factor transcripts: different deadenylation kinetics and uncoupling from translation. Molecular and Cellular Biology 15 5777-5788.

Cleveland D \& Yen T 1989 Multiple determinants of eukaryotic mRNA stability. New Biologist 1 121-126.

Cochrane AW \& Deely RG 1988 Estrogen-dependent activation of the avian very low density apolipoprotein II and vitellogenin genes. Transient alterations in mRNA polyadenylation and stability during induction. Fournal of Molecular Biology 203 555-567.

Coller JM, Gray NK \& Wickens MP 1998 mRNA stabilization by poly(A) binding proteins is independent of poly(A) and requires translation. Genes and Devlopment 12 3226-3234.

Cox RF 1977 Estrogen withdrawal in chick oviduct. Selective loss of high abundance classes of polyadenylated messenger RNA. Biochemistry 16 3433-3443.

Craig AWB, Haghighat A, Yu ATK \& Sonenberg N 1998 Interaction of polyadenylate binding protein with the eIF4 G homologue PAIP enhances translation. Nature 392 520-523.

Deardorff JA \& Sachs AB 1997 Differential effects of aromatic and charged residue substitutions in the RNA binding domains of the yeast poly(A) binding protein. Fournal of Molecular Biology 267 67-81.

Decker C \& Parker R 1993 A turnover pathway for both stable and unstable mRNAs in yeast: evidence for a requirement for deadenylation. Genes and Development 7 1632-1643.

DeMaria CT \& Brewer G 1996 AUF1 binding affinity to $\mathrm{A}+\mathrm{U}$-rich elements correlates with rapid mRNA degradation. Fournal of Biological Chemistry 271 12179-12184.

DeMaria CT, Sun Y, Long L, Wagner B \& Brewer G 1997 Structural determinants in AUF1 required for high affinity binding to A+U-rich elements. Fournal of Biological Chemistry 272 27635-27643.

Deo RC, Bonanno JB, Sonenberg N \& Burley SK 1999 Recognition of polyadenylate RNA by the poly(A)-binding protein. Cell 98 835-845.

Diamond DJ \& Goodman HM 1985 Regulation of growth hormone messenger RNA synthesis by dexamethasone and triiodthyronine: transcriptional rate and mRNA stability changes in pituitary tumor cells. Fournal of Molecular Biology 181 41-62.

Dodson RE \& Shapiro DJ 1994 An estrogen-inducible protein binds specifically to a sequence in the $3^{\prime}$ untranslated region of estrogen-stabilized vitellogenin mRNA. Molecular and Cellular Biology 14 3130-3138.

Dodson RE \& Shapiro DJ 1997 Vigilin, a ubiquitous protein with $14 \mathrm{~K}$ homology domains, is the estrogen inducible vitellogenin mRNA 3 '-untranslated region-binding protein. Fournal of Biological Chemistry 272 12249-12252.

Dodson RE, Acena MR \& Shapiro DJ 1995 Tissue distribution, hormone regulation and evidence for a human homologue of the estrogen-inducible Xenopus laevis vitellogenin mRNA binding protein. Fournal of Steroid Biochemical and Molecular Biology 52 505-515. 
Dreyfuss G, Hentze M \& Lamond AI 1996 From transcript to protein. Cell 85 963-972.

El Meskini R, Boudouresque F \& Ouafik L 1997 Estrogen regulation of peptidylglycine $\alpha$-amidating monooxygenase messenger ribonucleic acid levels by a nuclear posttranscriptional event. Endocrinology 138 5256-5265.

Fan XC \& Steitz JA 1998 Overexpression of NuR, the nuclear-cytoplasmic shuttling protein, increases the in vivo stability of ARE-containing mRNAs. EMBO Fournal 17 3448-3460.

Fan H, Villegas C, Huang A \& Wright JA 1996 Suppression of malignancy by the 3 ' untranslated regions of ribonucleotide reductase R1 and R2 messenger RNAs. Cancer Research $\mathbf{5 6}$ 4366-4369.

Ford L, Bagga P \& Wilusz J 1997 The poly(A) tail inhibits the assembly of a $3^{\prime}$-to-5' exonuclease in an in vitro RNA stability system. Molecular and Cellular Biology 17 398-406.

Ford LP, Watson J, Keene JD \& Wilusz J 1999 ELAV proteins stabilize deadenylated intermediates in a novel in vitro $\mathrm{mRNA}$ deadenylation/degradation system. Genes and Development 13 188-201.

Fujimoto JM, Narayanan CS, Benjamin JE \& Gershengorn MC 1992a Posttranscriptional up-regulation of thyrotropin-releasing hormone $(\mathrm{TRH})$ receptor messenger ribonucleic acid by TRH in COS-1 cells transfected with mouse pituitary TRH receptor complementary deoxyribonucleic acid. Endocrinology 131 1716-1720.

Fujimoto JM, Narayanan CS, Benjamin JE, Heinflink M \& Gershengorn MC $1992 b$ Mechanism of regulation of thyrotropin-releasing hormone receptor messenger ribonucleic acid in stably transfected rat pituitary cells. Endocrinology 130 1879-1884.

Furuichi Y, LaFiandra A \& Shatkin AJ 1977 5'-Terminal structure and mRNA stability. Nature 266 235-239.

Gallie D 1991 The cap and poly(A) tail function synergistically to regulate mRNA translational efficiency. Genes and Development 5 2108-2116.

Gallie DR 1998 A tale of two termini: a functional interaction between the termini of an $\mathrm{mRNA}$ is a prerequisite for efficient translation initiation. Gene 216 1-11.

Görlach M, Burd C \& Dreyfuss G 1994 The mRNA poly(A) binding protein: localization, abundance, and RNA-binding specificity. Experimental Cell Research 211 400-407.

Gorospe M \& Baglioni C 1994 Degradation of unstable interleukin- $1 \alpha$ mRNA in a rabbit reticulocyte cell-free system. Fournal of Biological Chemistry 269 11845-11851.

Guyette WA, Matusik RJ \& Rosen JM 1979 Prolactinmediated transcriptional and posttranscriptional control of casein gene expression. Cell 17 1013-1023.

Hagan KW, Ruiz-Echervarria MJ, Quan Y \& Peltz SW 1995 Characterization of cis-acting sequences and decay intermediates involved in nonsense-mediated mRNA turnover. Molecular and Cellular Biology 15 809-823.

Hargrove JL \& Schmidt FH 1989 The role of mRNA and protein stability in gene expression. FASEB Fournal 3 2360-2370.

Heaton B, Decker C, Muhlrad D, Donahue J, Jacobson A \& Parker R 1992 Analysis of chimeric mRNAs derived from the STE3 mRNA identifies multiple regions within yeast mRNAs that modulate mRNA decay. Nucleic Acids Research $205365-5373$.

Higgs DC \& Colbert JT 1994 Oat phytochrome A mRNA degradation appears to occur via two distinct pathways. Plant Cell 6 1007-1019.

Imataka H, Gradi A \& Sonenberg N 1998 A newly identified $\mathrm{N}$-terminal amino acid sequence of human eIF4 G binds
poly(A)-binding protein and functions in poly(A)-dependent translation. EMBO fournal 17 7480-7489.

Iwai M, Yasuda K, Fukuoko M, Iwai T, Takakura K, Taii S, Nakanishi S \& Mori T 1991 Luteinizing hormone induces progesterone receptor gene expression in cultured porcine granulosa cells. Endocrinology 129 1621-1627.

Izzauralde E \& Mattaj IW 1995 RNA export. Cell 81 153-159.

Izzauralde E, Lewis J, Gamberi C, Jarmolowski A, McGuigan C \& Mattaj IW 1995 A cap-binding protein complex mediating U snRNA export. Nature 376 709-712.

Jackson R \& Standart N 1990 Do the poly(A) tail and 3 'untranslated region control mRNA translation? Cell 62 $15-24$.

Jacobsen A \& Peltz SW 1996 Interrelationships of the pathways of mRNA decay and translation in eukaryotic cells. Annual Reviews in Biochemistry 65 693-739.

Jain RG, Andrews LG, McGowan KM, Pekala PH \& Keene JD 1997 Ectopic expression of Hel-N1, an RNA-binding protein, increases glucose transporter (GLUT 1) expression in 3T3-L1 adipocytes. Molecular and Cellular Biology 17 954-962.

Jones PM, Burrin JM, Ghatei MA, O’Halloran DJ, Legon S \& Bloom SR 1990 The influence of thyroid hormone status on the hypothalamo-hypophyseal-growth hormone axis. Endocrinology 126 1374-1379.

Joseph B, Orlian M \& Furneaux H 1998 p21 waf1 mRNA contains a conserved element in its 3 'untranslated region that is bound by the elav-like mRNA-stabilizing proteins. Fournal of Biological Chemistry 273 20511-20516.

Kanamori H, Dodson RE \& Shapiro DJ 1998 in vitro genetic analysis of the RNA binding site of vigilin, a multi-KH-domain protein. Molecular and Cellular Biology 18 3991-4003.

Kash JC \& Menon KMJ 1998 Identification of a hormonally regulated luteinizing hormone/human chorionic gonadotropin receptor mRNA binding protein. Fournal of Biological Chemistry 273 10658-10664.

Keller W \& Minvielle-Sebastia L 1997 A comparison of mammalian and yeast pre-mRNA 3 '-end processing. Current Opinion in Cell Biology 9 329-336.

Kimura N, Arai K, Sahara Y, Suzuki H \& Kimura N 1994 Estradiol transcriptionally and posttranscriptionally up-regulates thyrotropin-releasing hormone receptor messenger ribonucleic acid in rat pituitary cells. Endocrinology 134 432-440.

Klausner RD, Rouault TA \& Harford JB 1993 Regulating the fate of mRNA: the control of cellular iron metabolism. Cell 72 19-28.

Krane I, Spindel E \& Chin WW 1991 Thyroid hormone decreases the stability and the poly(A) tract length of rat thyrotropin $\beta$-subunit messenger RNA. Molecular Endocrinology 14 7984-7995.

Kruse C, Gruneweller A, Notbohn H, Kugler S, Purschke WG \& Muller PK 1996 Evidence for a novel cytoplasmic tRNA-protein complex containing the $\mathrm{KH}$-multidomain protein vigilin. Biochemical fournal 320 247-252.

Kugler S, Grunweller A, Probst C, Klinger M, Muller PK \& Kruse C 1996 Vigilin contains a functional nuclear localisation sequence and is present in both the cytoplasm and the nucleus. FEBS Letters 382 330-334.

Lafon I, Carballes F, Brewer G, Poiret M \& Morello D 1998 Developmental expression of AUF1 and HuR, two c-myc mRNA binding proteins. Oncogene 16 3413-3421.

Lagnado C, Brown C \& Goodall G 1994 AUUUA is not sufficient to promote poly(A) shortening and degradation of an mRNA: the functional sequence within AU-rich elements may be UUAUUUA(U/A)(U/A). Molecular and Cellular Biology 14 7984-7995. 
Laird-Offringa IA 1991 Degradation of c-myc mRNA. PhD Thesis, University of Leiden, The Netherlands.

Laroia G, Cuesta R, Brewer G \& Schneider RJ 1999 Control of mRNA decay by heat shock-ubiquitin-proteasome pathway. Science 284 499-502.

Le H, Tanguay R, Balasta ML, Wei C, Browning K, Metz A, Goss D \& Gallie D 1997 Translation initiation factors eIF-iso $4 \mathrm{G}$ and eIF-4B interact with the poly(A) binding protein and increase its RNA binding activity. Fournal of Biological Chemistry 272 16247-16255.

Leedman PJ, Stein AR \& Chin WW 1995 Regulated specific protein binding to a conserved region of the thyrotropin $\beta$-subunit mRNA 3'-untranslated region. Molecular Endocrinology 9 375-387.

Leedman PJ, Stein AR, Chin WW \& Rogers JT 1996 Thyroid hormone modulates the interactions between iron regulatory proteins and the ferritin mRNA iron-responsive element. Fournal of Biological Chemistry 271 12017-12023.

Levine TD, Gao F, King PH, Andrews LG \& Keene JD 1993 Hel-N1, an autoimmune RNA-binding protein with specificity for 3'uridylate-rich untranslated regions of growth faactor mRNAs. Molecular and Cellular Biology 13 3494-3504.

Levy A \& Lightman SL 1990 Bromocriptine reduces rat thyrotropin $\beta$-subunit mRNA stability. Fournal of Endocrinological Investigations 13 49-53.

Levy N, Chung S, Furneaux H \& Levy A 1998 Hypoxic stabilization of vascular endothelial growth factor mRNA by the RNA binding protein HuR. Fournal of Biological Chemistry 273 6417-6423.

Liebold EA \& Munro H 1988 Cytolpasmic proteins bind in vitro to a highly conserved sequence in the $5^{\prime}$ untranslated region of ferritin heavy- and light-subunit mRNAs. PNAS 85 2171-2175

Lok CN \& Ponka P 1999 Identification of a hypoxia response element in the transferrin receptor gene. Fournal of Biological Chemistry 274 24147-24152.

Lopez-Barahona M, Minano M, Mira E, Iglesias T, Stunnenberg HG, Rodriguez-Pena A, Bernal J \& Munoz A 1993 Retinoic acid posttranscriptionally up-regulates proteolipid protein gene expression in C6 glioma cells. Fournal of Biological Chemistry 268 25617-25623.

Lu DL, Peegel H, Mosier SM \& Menon KMJ 1993 Loss of lutropin/human choriogonadotropin receptor messenger ribonucleic acid during ligand-induced down-regulation occurs post transcriptionally. Endocrinology 132 235-240.

McCulloch RK, Walker CE, Chakera A, Jazayeri J \& Leedman PJ 1998 Regulation of EGF-receptor expression by EGF and $\mathrm{TGF} \alpha$ in epidermoid cancer cells is cell type specific. International Fournal of Biochemistry and Cell Biology 30 $1265-1278$.

McKnight GS \& Palmiter RD 1979 Transcriptional regulation of the ovalbumin and conalbumin genes by steroid hormones in chick oviduct. Fournal of Biological Chemistry 254 9050-9058.

Mangus DA \& Jacobson A 1999 Linking mRNA turnover and translation: assessing the polyribosomal association of mRNA decay factors and degradative intermediates. Methods $\mathbf{1 7}$ 28-37.

Marcotrigiano J, Gingras AC, Sonenberg N \& Burley SK 1999 Cap-dependent translation initiation in eukaryotes is regulated by a molecular mimic of eIF4 G. Molecular Cell 3 $707-716$.

Maurer F, Tierney M \& Medcalf RL 1999 An AU-rich sequence in the $3^{\prime}$-UTR of plasminogen activator inhibitor type 2 (PAI-2) mRNA promotes PAI-2 mRNA decay and provides a binding site for nuclear HuR. Nucleic Acids Research 27 1664-1673.
Meyer BE, Meinkoth JL \& Malim MH 1996 Nuclear transport of human immunodeficiency virus type 1 , visna virus, and equine infectious anemia virus Rev proteins: identification of a family of transferable nuclear export signals. Fournal of Virology $702350-2359$.

Michael WM \& Dreyfuss G 1995 A nuclear export signal in hnRNP A1: a signal-mediated, temperature dependent nuclear protein export pathway. Cell 83 415-422.

Minvielle-Sabastia L, Preker PJ, Wiederkehr T, Strahm Y \& Keller W 1997 The major yeast poly(A)-binding protein is associated with cleavage factor IA and functions in premessenger RNA 3'-end formation. PNAS 94 7897-7902.

Muckenthaler M, Gray NK \& Hentze MW 1998 IRP1 binding to ferritin mRNA prevents the recruitment of small ribosomal subunit by the cap-binding complex. Molecular Cell 2 383-388.

Muhlrad D \& Parker R 1994 Premature translational termination triggers mRNA decapping. Nature 340 $578-581$

Muhlrad D, Decker CJ \& Parker R 1994 Deadenylation of the unstable mRNA encoded by the yeast MFA2 gene leads to decapping followed by $5^{\prime}$ to $3^{\prime}$ digestion of the transcript. Genes Development 8 855-866.

Muhlrad D, Decker CJ \& Parker R 1995 Turnover mechanisms of the stable yeast PGK1 mRNA. Molecular and Cellular Biology 15 2145-2156.

Munroe D \& Jacobson A 1990 mRNA poly(A) tail, a 3' enhancer of translational initiation. Molecular and Cellular Biology 10 3441-3455.

Murphy D, Pardy K, Seah V \& Cartner D 1992 Posttranscriptional regulation of rat growth hormone gene expression: increased message stability and nuclear polyadenylation accompany thyroid hormone depletion. Molecular and Cellular Biology 12 2624-2632.

Myer VE, Fan XC \& Steitz JA 1997 Identification of HuR as a protein implicated in AUUUA-mediated mRNA decay. EMBO fournal 16 2130-2139.

Nagy E \& Rigby WF 1995 Glyceraldehyde-3-phosphate dehydrogenase selectively binds AU-rich RNA in the $\mathrm{NAD}(+)$-binding region. Fournal of Biological Chemistry 270 2755-2763.

Najmabadi H, Rosenberg LA, Yuan OX, Bhatia N, Albiston AL, Burger H \& Bhasin S 1993 Transcriptional and posttranscriptional regulation of inhibin alpha-subunit gene expression in rat Sertoli cells by 8 -bromo- $3^{\prime}, 5^{\prime}$-cyclicadenosine. Molecular Endocrinology 7 469-476.

Narayan CS, Fujimoto JM, Geras-Raaka E \& Gershengorn MC 1992 Regulation by thyrotropin-releasing hormone (TRH) of TRH receptor mRNA degradation in rat pituitary GH3 cells. Fournal of Biological Chemistry 267 17296-17303.

Nielsen DA \& Shapiro DJ $1990 a$ Insights into hormonal control of messenger RNA stability. Molecular Endocrinology 5 953-957.

Nielsen DA \& Shapiro DJ $1990 b$ Estradiol and estrogen receptor-dependent stabilization of minivitellogenin mRNA lacking 5100 nucleotides of coding sequence. Molecular and Cellular Biology 10 371-376.

Nielsen FC \& Christiansen J 1992 Endonucleolysis in the turnover of insulin-like growth factor II mRNA. Fournal of Biological Chemistry 267 19404-19411.

Paek I \& Axel R 1987 Glucocorticoids enhance stability of growth hormone mRNA. Molecular and Cellular Biology 7 1496-1507.

Park D, Cheon M, Kim C, Kim K \& Ryu K 1995 Progesterone together with estradiol promotes luteinizing hormone beta-subunit mRNA stability in rat pituitary cells cultured in vitro. European Fournal of Endocrinology 134 236-242. 
Paul SJ, Ortolano GA, Haisenleder DJ, Stewart JM, Shupnik MA \& Marshall JC 1990 Gonadotropin subunit messenger RNA concentrations after blockade of gonadotropin-releasing hormone action: testosterone selectively increases follicle stimulating hormone $\beta$-subunit messenger RNA by posttranscriptional mechanisms. Molecular Endocrinology 4 1943-1955.

Peltz SW, Brown AH \& Jacobson A 1993 mRNA stabilization triggered by premature translation termination depends on three mRNA sequence elements and at least one trans-acting factor. Genes and Development 7 1737-1754.

Posch M, Sutterluety H, Skern T \& Seiser C 1999 Characterization of the translational-dependent step during iron-regulated decay of transferrin receptor mRNA. Fournal of Biological Chemistry 274 16611-16618.

Presse F, Cardona B, Borsu L \& Nahon JL 1997 Lithium increases melanin-concentrating hormone mRNA stability and inhibits tyrosine hydroxylase gene expression in PC12 cells. Brain Research. Molecular Brain Research 52 270-283.

Pyronnet S, Imataka H, Gingras AC, Fukunaga R, Hunter T \& Sonenberg N 1999 Human eukaryotic translation initiation factor $4 \mathrm{G}(\mathrm{eIF} 4 \mathrm{G})$ recruits mnk1 to phosphorylate eIF4E. EMBO Yournal 18 270-279.

Raikhinstein M \& Hanukoglu I 1993 Mitochondrial-genomeencoded RNAs: differential regulation by corticotropin in bovine adrenocortical cells. PNAS 90 10509-10513.

Robinson BG, Frim DM, Schwartz WJ \& Majzoub JA 1988 Vassopressin mRNA in the suprachiasmatic nuclei: daily regulation of polyadenylate tail length. Science $241342-$ 344.

Ross DS, Downing MF, Chin WW, Kieffer JD \& Ridgeway EC 1983 Changes in tissue concentrations of thyrotropin, free thyrotropin $\beta$ and $\alpha$ subunits after thyroxine administration: comparison of mouse hypothyroid pituitary and thyrotropic tumors. Endocrinology 112 2050-2053.

Sachs A, Davis R \& Kornberg R 1987 A single domain of yeast poly(A) binding protein is necessary and sufficient for RNA binding and cell viability. Molecular and Cellular Biology 7 3268-3276.

Sachs AB, Sarnow P \& Hentze MW 1997 Starting at the beginning, middle and end: translation initiation in eukaryotes. Cell 89 831-838.

Seth D, Shaw K, Yeap BB, Jazayeri J, McCulloch RK \& Leedman PJ 1999 Complex transcriptional and posttranscriptional regulation of EGF-receptor expression by $\mathrm{EGF}$ and $\mathrm{TGF} \alpha$ in human prostate cancer cells. British Fournal of Cancer 80 657-669.

Shaw G \& Kamen R 1986 A conserved AU sequence from the 3 'untranslated region of GM-CSF mRNA mediates selective mRNA degradation. Cell 46 659-667.

Shimotohno K, Kodama Y, Hashimoto J \& Miura KI 1977 Importance of $5^{\prime}$-terminal blocking structure to stabilize mRNA in eukaryotic protein synthesis. PNAS 18 5799-5805.

Shupnik MA, Chin WW, Habener JF \& Ridgeway EC 1985 Transcriptional regulation of thyrotropin subunit genes by thyroid hormone. Fournal of Biological Chemistry 260 2900-2903.

Shyu A-B, Greenberg M \& Belasco J 1989 The c-fos transcript is targeted for rapid decay by two distinct mRNA degradation pathways. Genes and Development 3 60-72.

Shyu AB, Belasco JG \& Greenberg ME 1991 Two distinct destabilizing elements in the $c$-fos message trigger deadenylation as the first step in rapid mRNA decay. Genes and Development 5 221-231.

Simonet WS \& Ness GC 1989 Posttranscriptional regulation of 3-hydroxy-3-methylglutaryl-CoA reductase mRNA in rat liver. Fournal of Biological Chemistry 264 569-573.
Smith B, Gallie D, Le H \& Hansma P 1997 Visualization of poly(A)-binding protein complex formation with poly(A) RNA using atomic force microscopy. Fournal of Structural Biology 119 109-117.

Sonenberg N 1996 mRNA 5' cap-binding protein eIF4E and control of cell growth. In Translational Control, pp 245-269. Eds JWB Hershey, MB Mathews \& N Sonenberg. Cold Spring Harbour New York: Cold Spring Harbour Laboratory Press.

Song M-KH, Dozin B, Grieco D, Rall JE \& Nikodem VM 1988 Transcriptional activation and stabilization of malic enzyme mRNA precurser by thyroid hormones. Fournal of Biological Chemistry 263 1790-1794.

Staton JS \& Leedman PJ 1998 Posttranscriptiona regulation of thyrotropin $\beta$-subunit messenger ribonucleic acid by thyoid hormone in murine thyrotrope tumour cells: a conserved mechanism across species. Endocrinology 139 1093-1100.

Stevens A 1993 Eukaryotic nucleases and mRNA turnover In Control of Messenger RNA Stability, pp 449-471. Eds J Belasco \& G Brawerman. San Diego: Academic Press Inc.

Stoeckle MY \& Hanafusa M 1989 Processing of 9E3 mRNA and regulation of its stability in normal and rous sarcoma virus-transformed cells. Molecular and Cellular Biology 9 288-295.

Strickland S, Huarte J, Beilin D, Vassalli A, Rickles RJ \& Vassalli JD 1988 Antisense RNA directed against the 3' noncoding region prevents dormant mRNA activation in mouse oocytes. Science 24 680-684.

Surks MI \& Litschitz BM 1977 Biphasic thyrotropin suppression in euthyroid and hypothyroid rats. Endocrinology $101769-775$.

Tanguay R \& Gallie D 1996 Translational efficiency is regulated by the length of the $3^{\prime}$ untranslated region. Molecular and Cellular Biology 16 146-156.

Tano M, Minegishi T, Nakamura K, Karino S, Ibuki Y \& Miyamoto K 1997 Transcriptional and posttranscriptional regulation of $\mathrm{FSH}$ receptor in rat granulosa cells by cyclic AMP and activan. Fournal of Endocrinology 153 465-473.

Tarun SZ \& Sachs AB 1996 Association of the yeast poly(A) tail binding protein with translation initiation factor eIF-4 G. EMBO fournal 15 7168-7177.

Tilly JL, LaPolt PS \& Hsueh AJW 1992 Hormonal regulation of follicle-stimulating hormone receptor messenger ribonucleic acid levels in cultured rat granulosa cells. Endocrinology 130 1296-1302.

Thomson AM, Rogers JT \& Leedman PJ 1999a Ironregulatory proteins, iron-responsive elements, and ferritin translation. International Fournal of Biochemistry and Cellular Biology 31 1139-1152.

Thomson AM, Rogers JT, Walker C, Staton J \& Leedman PJ $1999 b$ Optimized RNA gel-shift and UV cross-linking assays for characterization of cytoplasmic RNA-protein interactions. Biotechniques 27 1032-1042.

Tuite M 1996 Death by decapitation for mRNA. Nature 382 $577-579$.

Visa N, Alzhanova-Ericsson AT, Sun X, Kiseleva E, Bjorkroth B, Wurtz T \& Daneholt B 1996 A pre-mRNAbinding-protein accompanies the RNA from the gene through the nuclear pores and into polysomes. Cell $\mathbf{8 4}$ 253-264.

Waskiewicz AJ, Johnson JC, Penn B, Mahaligam M, Kimball SR \& Cooper JA 1999 Phosphorylation of the cap-binding protein eukaryotic translation initiation factor $4 \mathrm{E}$ by protein kinase Mnk1 in vivo. Molecular and Cellular Biology 19 1871-1880.

Weiss IM \& Liebhaber SA 1995 Erythroid cell specific mRNA stability elements in the alpha 2-globin $3^{\prime}$ nontranslated region. Molecular and Cellular Biology 15 2457-2465. 
Weiss G, Houston T, Kastner S, Jöhrer K, Grünewald K \& Brock JH 1997 Regulation of cellular iron metabolism by erythropoietin: activation of iron-regulatory protein and upregulation of transferrin receptor expression in erythroid cells. Blood 89 680-687.

Wickens M \& Stephenson P 1984 Role of the conserved AAUAAA sequence: four AAUAAA point mutants prevent messenger RNA 3' end formation. Science 226 1045-1051.

Wickens M, Anderson P \& Jackson RJ 1997 Life and death in the cytoplasm: messages from the $3^{\prime}$ end. Current Opinion in Genetics and Development 7 220-232.

Williams DL, Sensel M, McTigue M \& Binder R 1993 Hormonal and developmental regulation of mRNA turnover. In Control of Messenger RNA Stability, pp 161-197. Eds J Belasco \& G Brawerman. San Diego: Academic Press Inc.

Wilson GM \& Brewer G 1999 The search for trans-acting factors controlling messenger RNA decay. Progress in Nucleic Acid Research and Molecular Biology 62 257-291.

Wilson GM, Sun Y, Sellers J, Lu H, Penkar N, Dillard G \& Brewer G 1999 Regulation of AUF1 expression via conserved alternatively spliced elements in the $3^{\prime}$ untranslated region. Molecular and Cellular Biology 19 1056-4064.
Yeap BB, Krueger RG \& Leedman PJ 1999 Differential posttranscriptional regulation of androgen receptor gene expression by androgen in prostate and breast cancer cells. Endocrinology 140 3282-3291.

Yen TJ, Gay DA, Pachter JS \& Cleveland DW 1988 Autoregulation changes in stability of polyribosomal-bound $\beta$-tubulin mRNAs are specified by the first thirteen translated nucleotides. Molecular and Cellular Biology $\mathbf{8}$ 1224-1235.

Zhang W, Wagner BJ, Ehrenman K, Schaefer AW, DeMaria CT, Crater D, DeHaven K, Long L \& Brewer G 1993 Purification, characterization and $\mathrm{cDNA}$ cloning of an AU-rich element RNA-binding protein, AUF1. Molecular and Cellular Biology 13 7652-7665.

Zingg HH, Lefebvre DL \& Almazan G 1988 Regulation of poly(A) tail size of vassopressin mRNA. Fournal of Biological Chemistry 263 11041-11043.

Zubiaga AM, Belasco JG \& Greenberg ME 1995 The nonamer UUAUUUAUU is the key AU-rich sequence motif that mediates mRNA degradation. Molecular and Cellular Biology 15 2219-2230.

REVISED MANUSCRIPT RECEIVED 3 March 2000 